\title{
Behavior of the Combined Radial Post-feeding Larval Dispersal of the Blowflies Chrysomya megacephala and Chrysomya albiceps (Diptera, Calliphoridae) and implications for Forensic Entomology
}

\author{
Leonardo Gomes ${ }^{1 *}$, Marcos Rogério Sanches ${ }^{2}$ and Claudio José Von Zuben ${ }^{1}$ \\ ${ }^{I}$ Departamento de Zoologia; Universidade Estadual Paulista; Av. 24A, 1515, Bairro Bela Vista, 13506-900; Rio \\ Claro - SP - Brasil. ${ }^{2} I M E$; USP; Rua do Rocio 220; $1^{O}$ andar; Vila Olímpia; 04552-903; SP - Brasil
}

\begin{abstract}
The aims of this work was to study the life stages of Chrysomya megacephala in a circular arena allowing the combined radial post-feeding dispersal from the center of the arena of $\mathrm{C}$. albiceps and $\mathrm{C}$. megacephala larvae. To determine the location of each pupa, the distance from the center, the depth and weight of each pupa formed were analyzed. For the larvae of $\mathrm{C}$. albiceps, females released buried deeper than males, reaching an average depth of $10.74 \mathrm{~cm}$ and C. megacephala larvae presented greater average results than C. albiceps for all variables, particularly distance, which was $16.02 \mathrm{~cm}$ for this species and $12.30 \mathrm{~cm}$ for C. albiceps. C. albiceps larvae preyed on 30 C. megacephala larvae in both experiments. These results could be used in forensic entomology because the evaluation of Post Mortem Interval (PMI) was one of the most important aspects of legal medicine, and it could be underestimated if the older dispersing larvae or those that dispersed longer and faster or deeper, were not taken into account.
\end{abstract}

Key words: Blowflies, Calliphoridae, Dispersal, Forensic Entomology, Chrysomya albiceps and Chrysomya megacephala

\section{INTRODUCTION}

Chrysomya albiceps (Wiedemann) and $C$. megacephala (Fabricius) are calliphorid flies known to cause myiasis in humans and other animals and to transmit pathogens (e.g. bacteria and viruses) (Zumpt, 1965; Baumgartner and Greenberg, 1984; Maldonado and Centeno, 2003). These species were found in South America about 1975, together with Chrysomya putoria and rapidly dispersed throughout the Continent, with $C$. megacephala reaching the United States (Greenberg, 1988; Wells, 1991). This biological invasion has apparently caused the displacement of Cochliomyia macellaria, a native species to the Americas (Guimarães et al., 1979; Prado and Guimarães, 1982; Greenberg and Szyska, 1984). Chrysomya species in both immature and adult stages are the primary invertebrate consumers of decomposing organic matter such as carrion (Braack, 1986). The immature phase is the most important in terms of development since the larvae try to acquire the maximum amount of food to pupate (Levot et al., 1979). Shortly after the larvae obtained the minimum weight for pupation, they

* Author for correspondence 
leave the substrate dispersing around the carrion (Smith, 1986; Godoy et al., 1995)

Larval dispersal is an important process for the blowfly life cycle, since during this period larvae leave their food substrate searching for a suitable place to bury and pupate (Levot et al; 1979; Godoy et al., 1995, 1996). In this phase, the blowfly larvae may be at risk of predation, parasitation and dessication (Legner, 1977; Peschke et al. 1987). In previous studies, Godoy et al. (1995, 1996) and Boldrini et al. (1997) investigated experimentally and theoretically the dispersal of postfeeding larvae of $C$. megacephala, C. putoria and C. macellaria. These authors found that most larvae of $C$. megacephala, $C$. putoria and Co. macellaria pupated close to the food source. The maximum distance travelled by the larvae differed among the three species, with $C$. megacephala and $C$. putoria larvae reaching a maximum dispersal distance greater than $C o$. macellaria.

An analysis of frequency distribution in dispersing blowfly larvae revealed that aggregated distribution patterns emerged as a consequence of dispersal, and Co. macellaria had higher aggregation levels than $C$. megacephala and $C$. putoria (Godoy et al., 1996). The results found in these studies could be interesting and important for population dynamics of blowflies and forensic entomology (Boldrini et al., 1997; Von Zuben et al., 1998). However, the larval dispersal behaviour was studied considering only single species experiments. Very little is known about combined larval dispersal in blowflies (Gomes et al., 2002, 2003; Gomes and Von Zuben, 2003).

$C$. albiceps is a facultative predator of other dipteran larvae (Fuller, 1934; Coe, 1978; Gagné, 1981; Erzinçlioglu and Whitcombe, 1983) and this habit probably has important effects on prey species, particularly in communities where the reduction of the population size in native species is evident, in the presence of $C$. albiceps (Hanski, 1987; Goodbrood and Goff, 1990; Wells and Greenberg, 1992a,b,c). Faria et al. (1999) and Faria and Godoy (2001) investigated facultative predation rates on third instar larvae of $C o$. macellaria, C. putoria and C. megacephala by third instar larvae of $C$. albiceps in no choice, two choice and three choice situations. The highest predation rate occured on Co. macellaria larvae, suggesting that $C$. albiceps had a higher predation impact on Co. macellaria than on other blowflies (Faria et al., 1999).
Recently, Gomes et al. (2002, 2003) investigated the larval dispersal in experimental populations of C. albiceps and C. megacephala in single species experiments. For both species the number of recovered larvae of $C$. albiceps and $C$. megacephala was similar to the number initially released. However, the distance for burial of larvae of C. megacephala was significantly greater than the distance for burial of $C$. albiceps (Gomes et al., 2002, 2003). The results showed that $C$. megacephala larvae had a lower aggregation behavior during the dispersal processes than those of $C$. albiceps, probably due the fact that C. albiceps larvae could predate $C$. megacephala larvae during the dispersal.

In this paper, we analyzed the combined larval dispersal of C. albiceps and C. megacephala in a circular arena because the circular dispersal reflects more accurately the larval dispersal process that occured in the natural environment, when compared to some studies on calliphorid larval dispersal that have already been done as the case of Greenberg (1990) and other involving models such as those on post-feeding larval dispersal restricted to one direction based on diffusion equations (Bassanezi et al., 1997), on statistical analyses of spatial distribution (Godoy et al., 1995; 1996; Von Zuben et al., 1996; Kocarek, 2001a, 2001b), and on non-local interactions (Boldrini et al., 1997). All of these could be a basis for future experimental studies simulating the natural environment, as proposed in this study.

\section{MATERIAL AND METHODS}

Specimens of C. megacephala and C. albiceps were colleted around the Biosciences Institute of Unesp in Rio Claro, São Paulo, Brazil. Decaying organic matter of fish was used as bait and the specimens collected were maintained in screen cages in a controlled temperature room at $25 \pm$ $1{ }^{\circ} \mathrm{C}, 60 \%$ relative humidity and 12 -hour photoperiod.

Flasks with larval densities of both species were formed in macerated bovine meat. After the larvae of generation $F_{2}$ developed at $L_{3}$, the meat was placed in the center of a circular arena for them to move out of it. Two arenas (totally illuminated, to avoid tendencies in the dispersal) with $50 \mathrm{~cm}$ in diameter, covered with $20 \mathrm{~cm}$ of wood shavings 
were used. A total of 350 larvae were used in each trial: a test (350 larvae, 175 from each species) and a replicate (350 larvae, 175 from each species).

After the pupation, the individuals were located and removed from the wood shavings. The depth of the pupation site and its distance from the center of the arena were measured in centimeters with rulers and measuring tapes. Burial depth was measured in categories with numbers from 1 to 4 , where 1 represented the depth from 0 to $5 \mathrm{~cm}, 2$ represented $6-10 \mathrm{~cm}, 3$ represents $11-15 \mathrm{~cm}$ and 4 represented $16-20 \mathrm{~cm}$. The arena was divided in 72 sectors of 5 degrees each and the counting was done from its periphery to the center. The pupae were individualized in plastic flasks and weighed on an Ohaus analytical scale before the adults emerged. Pupal weight was measured in milligrams, with a precision of $0.01 \mathrm{mg}$. After they were weighted, the pupae were returned to their individual flasks for the identification of species and sex of the adults after their emergence.

\section{Statistical analysis}

The Rao test and Watson test were performed (the last applied to confirm the first test) to verify the homogeneity of distribution across sectors, and a correlation test was applied to check if there was a correlation between the variables analyzed. Student (t) test was used to check the equality of the variables: weight, depth and distance (between the species), considering an interval from -1.6 to 1.6 for the Stat $t$ test (standardized Student ( $t$ ) test), if there was equality for the variables (Zar, 1999). To check the uniformity of distribution of larvae of both species, the vector of uniformity was analyzed (Zar 1999; Bioestat 2.0) and ANOVA (at
5\%) was utilized to check the differences between two experiments.

\section{RESULTS}

Combined radial post-feeding larval dispersal in Chrysomya megacephala and Chrysomya albiceps (considering both species jointly)

Considering both arenas, from the total number of larvae released, 320 were collected on average: 145 of $C$. megacephala pupae and 175 of $C$. albiceps. This suggested that $C$. albiceps preyed on 30 C. megacephala larvae during the process of post-feeding dispersal, because there was no pupa found in the arena after the collected data neither an adult of both species flying. Values of average and standard deviation for burial depth, distance from the center of arenas and weight of the larvae in all four quadrants of the arena are represented in Table 1 . The first quadrant corresponds to sectors from 1 to $90^{\circ}$, the second quadrant from 91 to $180^{\circ}$, the third from 181 to $270^{\circ}$, and the forth from 271 to $360^{\circ}$. Considering the distribution of both species together in the arenas (Fig. 1), 33.4\% of the total preferred the quadrant 1 while only $11 \%$ went to quadrant 2 , results confirmed by Rao test and Watson test $\left(\mathrm{U}_{\mathrm{GL} 1, \mathrm{GL} 2}=0,4272 ; \mathrm{P}=0,05\right)$.

The presence of pupae (320) of each species in each quadrant is demonstrated in Fig. 2.

The number of $C$. albiceps pupae was greater in all quadrants, (except for quadrant 4) which indicated that $C$. albiceps larvae preyed on $C$. megacephala larvae. Considering the presence of pupae on different depths, both species preferred to pupate deeper (Fig. 3).

Table 1- Depth, distance and weight (average and standard deviation (SD)) of C. megacephala and C. albiceps pupae, in four quadrants of the arenas $50 \mathrm{~cm}$ in diameter.

\begin{tabular}{lllll}
\hline Quadrant & $\mathbf{1}$ & $\mathbf{2}$ & $\mathbf{3}$ & $\mathbf{4}$ \\
\hline $\begin{array}{l}\text { Average depth } \pm \\
\text { SD }(\mathrm{cm})\end{array}$ & $13.89 \pm 3.25$ & $13.21 \pm 4.16$ & $14.46 \pm 2.89$ & $14.32 \pm 5.45$ \\
\hline $\begin{array}{l}\text { Average distance } \pm \\
\text { SD }(\mathrm{cm})\end{array}$ & $18.79 \pm 1.23$ & $13.45 \pm 1.75$ & $17.43 \pm 2.25$ & $14.69 \pm 1.95$ \\
$\begin{array}{l}\text { Average weight } \pm \\
\text { SD }(\mathrm{cm})\end{array}$ & $45.68 \pm 5.56$ & $39.98 \pm 6.78$ & $44.56 \pm 5.68$ & $37.59 \pm 7.09$ \\
\hline
\end{tabular}




\section{Species distribution}

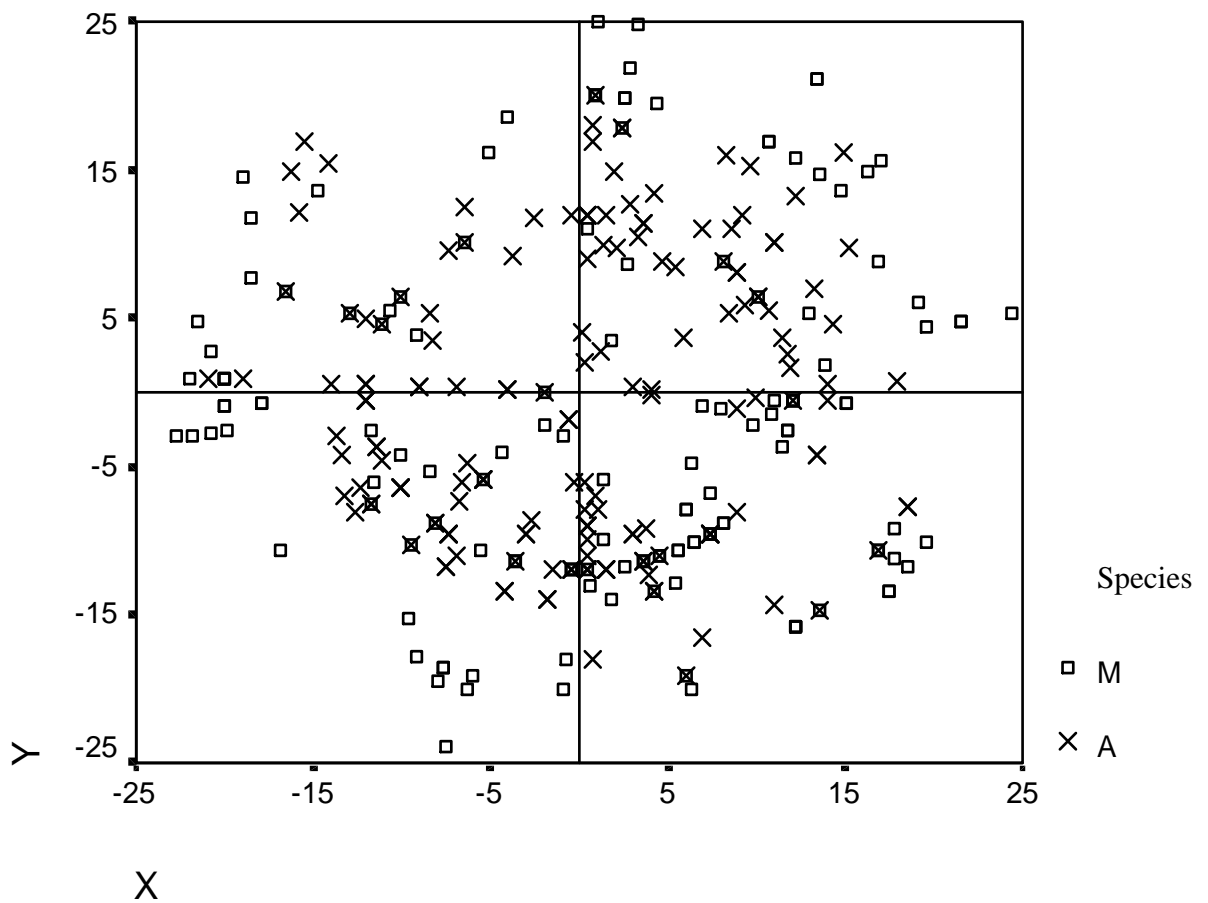

Figure 1- Species distribution in the dispersal arena (species $\mathrm{M}=$ C. megacephala and $\mathrm{A}=$ C. albiceps).

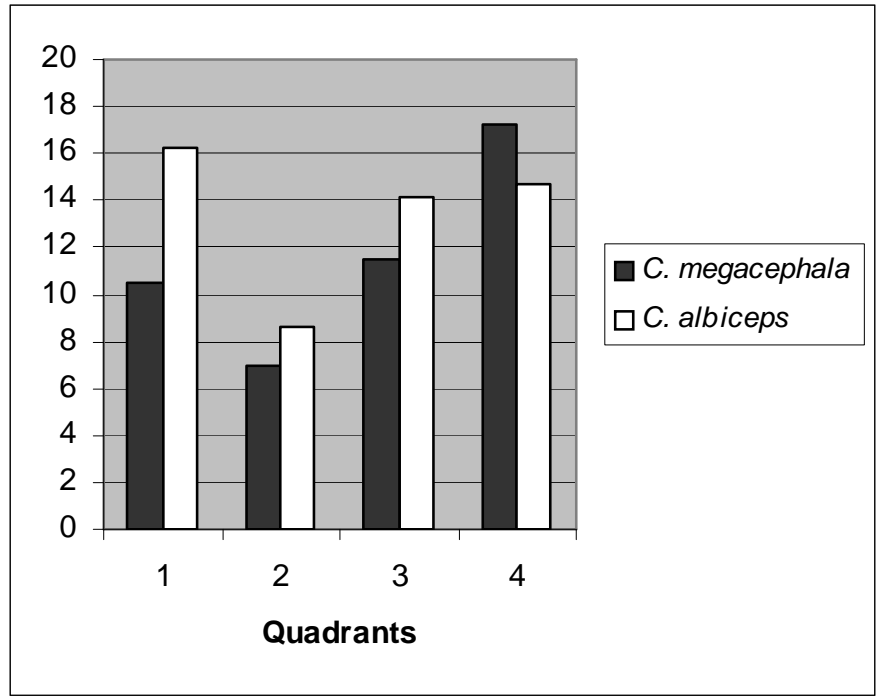

Figure 2- Pupal frequency (\%) (in y axis) per quadrant of C. albiceps and C. megacephala. 
The frequency of pupae in relation to their distances from the center of arena is illustrated in Fig. 4. Distances between 0 and $5 \mathrm{~cm}$ corresponded to the first interval, the second interval from 6 to $10 \mathrm{~cm}$, up to the fifth level, which corresponded to an interval from 21 to 25 $\mathrm{cm}$ of distance. Most pupae were concentrated in levels 3 and 4 (Fig. 4).
Analyzing the pupal weight distribution, the average pupation weight was $39.2 \mathrm{mg}$ and most pupae weighed between 37 and $43 \mathrm{mg}$ (Fig. 5). Table 2 showed both previous graphs regarding sex distribution; it demonstrated how each blowfly species was located according to gender.

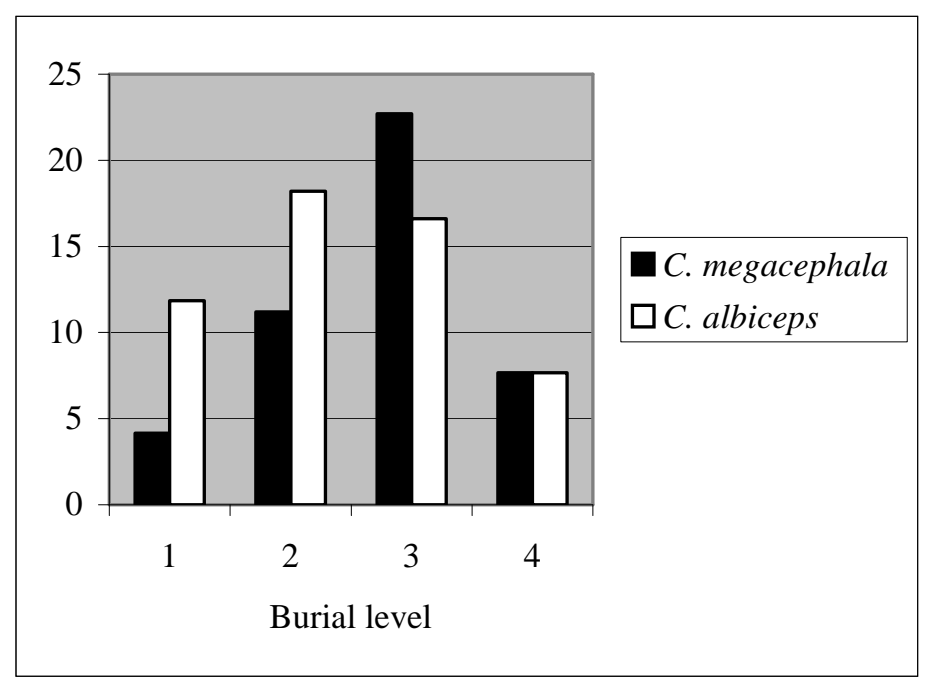

Figure 3- Pupal frequencies (in y axis) $(\mathrm{n}=350)$ of $C$. albiceps and C. megacephala at different burial levels.

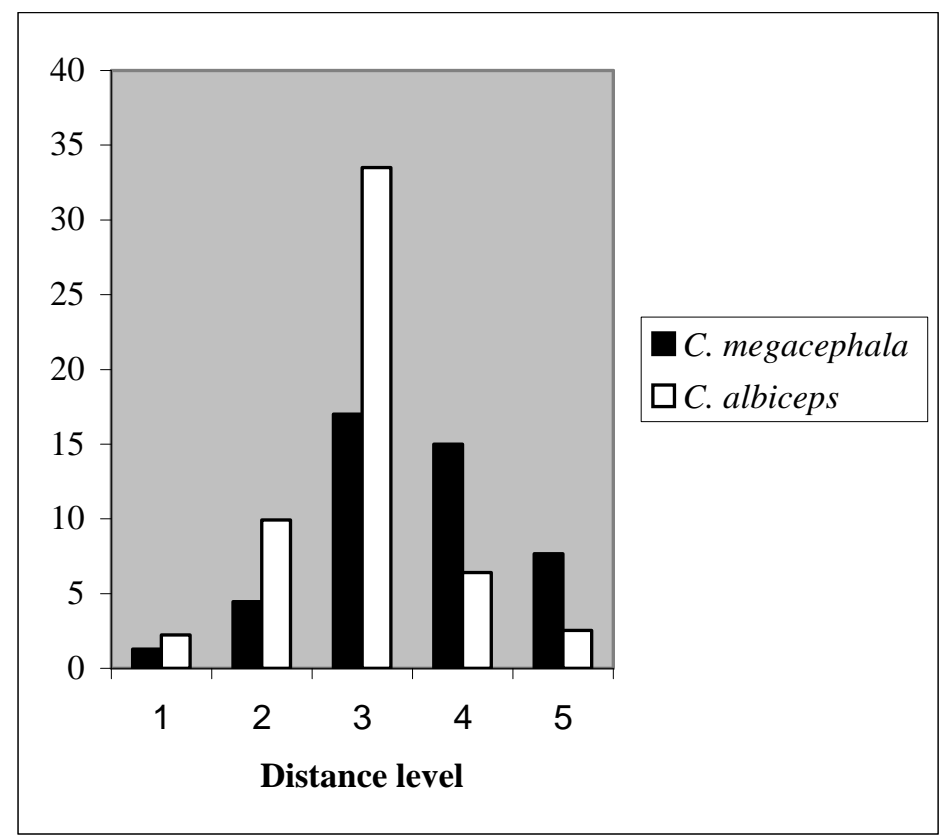

Figure 4 - Pupal frequencies $(\mathrm{n}=350)$ (in y axis) of C. albiceps and C. megacephala per distance level. 


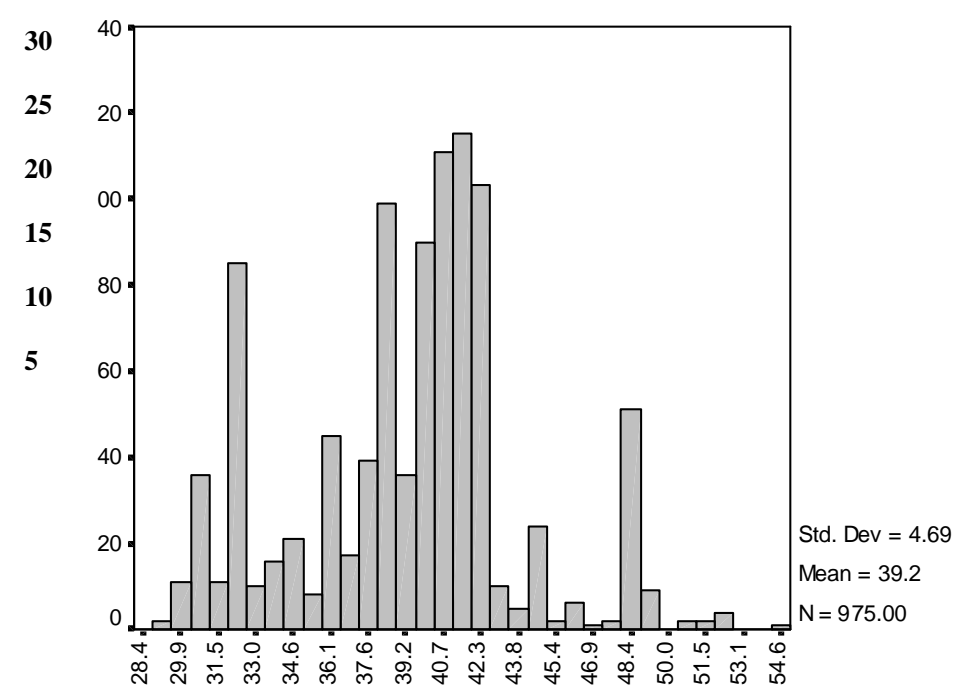

Weight (mg)

Figure 5- Number of C. albiceps (in y axis) and C. megacephala pupae per weight class.

Table 2- Distribution of C. albiceps and C. megacephala males (M) and females (F) according to each variable tested.

\begin{tabular}{|c|c|c|c|c|}
\hline \multicolumn{2}{|l|}{ Species } & \multirow{2}{*}{$\frac{\text { Gender }}{\mathrm{F}}$} & \multirow{2}{*}{$\begin{array}{r}\text { Mean } \\
11,83\end{array}$} & \multirow{2}{*}{$\begin{array}{c}\text { Number of pupae } \\
92\end{array}$} \\
\hline \multirow{9}{*}{ C. albiceps } & \multirow{3}{*}{ Distance $(\mathrm{cm})$} & & & \\
\hline & & M & 12,88 & 76 \\
\hline & & Total & 12,31 & 168 \\
\hline & \multirow{3}{*}{ Depth $(\mathrm{cm})$} & $\mathrm{F}$ & 10,74 & 92 \\
\hline & & $\mathrm{M}$ & 8,81 & 76 \\
\hline & & Total & 9,87 & 168 \\
\hline & & $\mathrm{F}$ & 39,53 & 92 \\
\hline & \multirow{3}{*}{ Weight (mg) } & M & 38,91 & 76 \\
\hline & & Total & 39,25 & 168 \\
\hline \multirow{9}{*}{ C. megace } & & $\mathrm{F}$ & 15,88 & 77 \\
\hline & \multirow[t]{2}{*}{ Distance $(\mathrm{cm})$} & $\mathrm{M}$ & 16,17 & 68 \\
\hline & & Total & 16,02 & 145 \\
\hline & \multirow{3}{*}{ Depth $(\mathrm{cm})$} & $\mathrm{F}$ & 11,78 & 77 \\
\hline & & $\mathrm{M}$ & 11,70 & 68 \\
\hline & & Total & 11,75 & 145 \\
\hline & \multirow{3}{*}{ Weight (mg) } & $\mathrm{F}$ & 38,81 & 77 \\
\hline & & M & 37,50 & 68 \\
\hline & & Total & 38,14 & 145 \\
\hline
\end{tabular}

Regarding burial depth, C. albiceps females buried deeper than males (Student $(\mathrm{t})$ at $5 \%$ of significance), reaching an average depth of 10.74 $\mathrm{cm}$ and $C$. megacephala females achieved weights higher than males (Student (t) at 5\%). Considering both species, $C$. megacephala larvae presented higher average results than $C$. albiceps for all variables, particularly distance, which was 16.02 $\mathrm{cm}$ for this species and $12.30 \mathrm{~cm}$ for $C$. albiceps. Chrysomya albiceps larvae preyed on $30 \quad C$. megacephala larvae in both experiments.

There was no significant difference between the experiments (ANOVA, p<2,78, at $5 \%$ of significance). Considering both species, depth as well as burial angle cosine was related to distance. Therefore, distance $=4.63+0.336$ depth +2.049 
cosine which could be interpreted as: for an $1 \mathrm{~cm}$ increase in depth, there was a mean distance increase of $0.336 \mathrm{~cm}$ and for an increase of 1 unit in burial angle cosine, there was an increase of $2.049 \mathrm{~cm}$ on average burial distance.

\section{Statistical analysis of data considering both species together}

Considering both species together, the correlation between distance and depth was $r=0.31$, which indicated a significant correlation due to sample size (350), but when the Student (t) test was applied to $r$ value of correlation, a value of $\mathrm{p}=$ 0,75 was obtained with $1 \%$ of significance $(\mathrm{df}=1$, $\mathrm{P}>0,03$ ), which means that there is no relation among the two variables. For the variables depth and weight, a correlation of $\mathrm{r}=0.11$ was obtained. When the Student (t) test was applied to $r$ value of correlation, a value of $\mathrm{p}=2,21$ was obtained with $1 \%$ of significance $(\mathrm{df}=1, \mathrm{P}>0,011)$, meaning that the heavier the larvae, the deeper they buried. Finally, regarding the variables weight and distance, a weak significant correlation of $\mathrm{r}=$ 0.075 was obtained. The Student $(\mathrm{t})$ test to $r$ value yielded a value of $\mathrm{p}=3.34$ with $1 \%$ of significance $(\mathrm{df}=1, \mathrm{P}>0,02)$ demonstrating that the farther the larvae are from the center, the less they weighed.

\section{Variance test checking the equality of the different variables (Stat $t$ - test)}

Considering the variable distance between both species, a Stat $\mathrm{t}$ value of 12.30 was obtained, indicating that the mean distances the two species traveled were not equal. C. albiceps larvae reached an average of $9,86 \mathrm{~cm}$ for burial depth and $C$. megacephala reached $11.74 \mathrm{~cm}$, which corresponded to a Stat $t$ value of -1.82 , showing that the average depth reached by both species wasn't equal. Finally, regarding weight, the mean values obtained were $41.56 \mathrm{mg}$ for $C$. albiceps and $44.12 \mathrm{mg}$ for $C$. megacephala, with a corresponding Stat $t$ value of 1.76 indicating that the weight averages of the two species were not close.

\section{DISCUSSION}

The present study demonstrated some general aspects on the dispersal process of larvae of $C$. megacephala and C. albiceps in a circular arena and confirmed former results using deeper arenas of smaller diameter (Gomes et al., 2003) where the lightest larvae tended to move longer distances, probably to search new sources of food, not only of a site to pupate (Gomes et al., 2002). Maybe the lightest larvae tended to move longer distances not only because they didn't reach the minimal weight for pupation, but because they weren't able to dispute by food with weightier larvae or were pushed away by the increasing of the temperature that these weightier larvae produced during the feeding.

The greatest concentration of pupae was found in distances between 11 and $13 \mathrm{~cm}$ and hence 18 larvae reached the maximum depth $(20 \mathrm{~cm})$. Apparently, distance was the most limiting parameter in this study, not burial depth from the center. The use of an arena with $50 \mathrm{~cm}$ in diameter and $20 \mathrm{~cm}$ of depth allowed the larvae to bury deeper than in other recent studies where the arena had $2 \mathrm{~m}$ in diameter and $5 \mathrm{~cm}$ depth, confirming that in short spaces larvae could bury deeper. (Gomes et al. 2003). Larval movement from the food substrate probably took place mainly to find a pupation site, though the possibility that some larvae were searching for an additional source of food could not be discarded (Gomes et al. 2002).

Considering the distribution of larvae per quadrant, quadrant 1 was preferred, while in other experiments where only one species was considered, an average of $33.47 \%$ preferred quadrant 1 and only $15.25 \%$ preferred quadrant 2 (Gomes et al. 2002, 2003). The statistical results analyzed suggest that larvae did not have any preference in distributing themselves in the quadrants. Thus, this aspect of larval distribution must be confirmed in future experiments. The total illumination of room, which was utilized to avoid tendencies in the pattern of larval dispersal, did not affect temperature and relative humidity, which presented little variation during the experiment.

Results of Godoy et al. (1995, 1996) demonstrated an oscillation in pupal frequency as a function of distance from the feeding substrate for $C$. megacephala as well as for $C$. putoria. According to Boldrini et al. (1997), these oscillations would be a consequence of the appearance of larval aggregations in certain sites of the pupation substrate. It is believed that the dispersing larvae can somehow feel the density of other larvae already buried in a certain area of the substrate. These studies have considered a trough of $3 \mathrm{~m}$ long and $30 \mathrm{~cm}$ wide for the larval dispersal process, allowing larval movements in only one direction. With the use of a circular arena, this 
study better reflected the conditions of the natural environment the larvae faced when they abandon their feeding substrate in search of a site to pupate (Ullyett, 1950) A circular arena allows a radial dispersal from a central feeding substrate unlike the dispersal in only one direction allowed by a trough.

On natural environment populations the postfeeding larval dispersal behavior and the consequent pattern of spatial distribution of pupae in pupation sites could have implications on greater or lesser larval susceptibility to predator or parasitoid attacks (Peschke et al., 1987; Legner, 1997). Chrysomya albiceps larvae prey on $C$. megacephala larvae during larval dispersal and the latter probably disperse farther and deeper, to escape predation (Goodbrod andGoof, 1990; Wells andGreenberg, 1992; Hanski, 1997; Faria et al., 1999, 2001).

One important aspect to be considered in the present study was that $C$. albiceps larvae did not distribute themselves uniformly in the arena, which differed from former experiments in which the species were considered separately (Gomes et al., 2003). Here, C. albiceps larvae concentrated closer to the center of the arena and did not show a uniform distribution (uniformity vector of 0.08 , significant), while $C$. megacephala larvae presented a uniform distribution (uniformity vector of 0.24 , significant). This could be related to the need to minimize the contact with $C$. albiceps larvae to avoid predation by them (Faria et al., 2001).

Finally, the main result found in this study was the change of aggregated to random pattern in relation to single cultures of $C$. megacephala (Gomes et al. 2003). This result could have implications for population dynamics of $C$. megacephala and the structure of necrophagous fauna, since the random distribution of larvae couldreduce attack rates of natural enemies such as parasitoids and predators (Legner, 1977; Peschke et al., 1987). Dispersal is one of the most significant aspects in the life history of insects (Turchin, 1989). The complexity of dispersal is further enhanced by the spatial scale in which it occurs, which may vary from centimeters (like the present study) to hundreds of kilometers (Gaines and Bertness, 1993).

The analysis of postfeeding larval dispersal of blowflies could have important implications for medico-criminal investigations considering forensic entomology, since the presence of larvae and pupae in the vicinities or under human corpses can aid in estimating their postmortem intervals (PMI) (Smith, 1986; Gomes andVon Zuben, 2003; Gomes et al. 2002, 2003). The evaluation of PMI is one of the most important aspects of legal medicine (Smith, 1986), and it could be underestimated if the dispersal of two or more species together and the older dispersing larvae or those that dispersed longer and faster or deeper, are not taken into account (Gomes andVon Zuben, 2003; Gomes et al. 2002, 2003). Then, it would necessary to investigate the pattern of larval dispersal on the pupation site, as demonstrated in this study with larvae of $C$. albiceps and $C$. megacephala.

\section{ACKNOWLEDGMENTS}

Leonardo Gomes has been supported by scholarships from FAPESP (00/06336-0) and Cláudio José Von Zuben by research fellowships from CNPq. To Iracema Monteiro da Silva collecting the data and referees by the comments.

\section{RESUMO}

O objetivo desse trabalho foi estudar estágios de vida de Chrysomya megacephala em uma arena circular permitindo a dispersão larval pósalimentar combinada a partir do centro das larvas de $C$. megacephala e C. albiceps. Para determinar a localização de cada pupa a distância a partir do centro, a profundidade e o peso foram coletados. Do total de larvas soltas as fêmeas de C. albiceps se enterraram mais profundamente que os machos, alcançando uma profundidade de $10,74 \mathrm{~cm}$. Apesar dessa diferença, as larvas de $C$. megacephala apresentaram resultado em média maiores para todas a variáveis, particularmente a distância, a qual foi $16,02 \mathrm{~cm}$ para essa espécie e 12,30 para $C$. albiceps. Além disso, as larvas de $C$. albiceps predaram 30 larvas de $C$. megacphala durante esse processo em ambos os experimentos. Esses estudos podem ser utilizados em Entomologia forense porque a estimativa do Intervalo Pós Morte (IPM) é um dos aspectos mais importantes em medicina legal e a não consideração das larvas que dispersam mais longe ou se enterram mais podem levar a uma subestimativa do IPM. 


\section{REFERENCES}

Baumgartner D. L. and Greenberg B. (1984), The genus Chrysomya (Diptera: Calliphoridae) in the New World. J. Med. Ent., 21, 105-113.

Braack, L. E. O. (1986). Arthropods associated with carcasses in the northern Kruger National Park. $S$. Afr. J. Wild. Res., 16, 91-98.

Bassanezi, R. C., M. B. F., Leite, Godoy, W. A. C., Von Zuben, C. J., Von Zuben, F. J. and Reis, S. F. (1997), Diffusion model applied to postfeeding larval dispersal in blowflies (Diptera: Calliphoridae). Mem. Inst. Oswaldo Cruz 92, 281-286.

Boldrini, J. L., Bassanezi, R. C., Moretti, A. C., Von Zuben, F. J., Godoy, W. A. C., Von Zuben, C. J. and Reis, S. F. (1997), Non-local interactions and the dynamics of dispersal in immature insects. J. Theor. Biol., 185: 523-531.Gaines, S. D. and Bertness (1993). The dynamics of juvenile dispersal: why field ecologists must integrate. Ecology, 74, 2430-2435.

Coe, R. L. (1978), The decomposition of elephant carcases in the Tsavo (East) National, Kenya. J. Ar. Env., 1, 71-86.

Erzinçlioglu, Y. Z. and Whitcombe, R. P. (1983), Chrysomya albiceps (Wiedemann) (Dipt. Calliphoridae) in dung and causing myiasis in Oman. Ent.Mon.Mag., 119, 51-52.

Faria, L. D. B., Orsi, L., Trinca, L. A. and Godoy, W. A. C. (1999), Larval predation by Chrysomya albiceps on Cochliomyia macellaria, Chrysomya megacephala and Chrysomya putoria. Ent. Exp. Appl., 90, 149-155.

Faria, L. D. B. and Godoy, W. A. C. (2001), Prey choice by facultative predator larvae of Chrysomya albiceps (Diptera: Calliphoridae). Mem. Inst. Oswaldo Cruz, 96, 875-878.

Fuller, M. E. (1934), The insect inhabitants of carrion, a study in animal ecology. Bull. Coun. Sci. Ind. Res., Melbourne, 82, 5-62.

Gagné, R.J. (1981), Chrysomya spp., Old World blowflies (Diptera, Calliphoridae), recently established in the Americas. Bull. Ent. Soc. Am., 27, 21-22.

Gaines, S. D. and Bertness (1993), The dynamics of juvenile dispersal: why field ecologists must integrate. Ecology, 74, 2430-2435.

Godoy, W. A. C., Fowler, H. G., Von Zuben, C. J., Ziti, L and Ribeiro, O. R. (1995), Larval dispersal in Chrysomya megacephala, Chrysomya putoria and Cochliomyia macellaria (Dipt., Calliphoridae). J. App. Ent., 119, 263-266.

Godoy, W. A. C., Von Zuben, C. J. and Reis, S. F. (1996), Larval dispersal in Chrysomya megacephala, Chrysomya putoria and Cochliomyia macellaria (Dipt., Calliphoridae): ecological implications of aggregation behaviour. J. Appl. Ent., 120, 423-426.
Gomes, L., Von Zuben, C. J. andGovone, J. S. (2002), Comportamento da dispersão larval radial pósalimentar em moscas-varejeiras do gênero Chrysomya (Diptera: Calliphoridae): busca por novas fontes de alimento. Entom. Vect. 9, 115 - 132.

Gomes, L. andVon Zuben, C. J. (2003), Distribuição larval radial pós- alimentar em Chrysomya albiceps (Wied.) (Diptera: Calliphoridae): profundidade, distância e peso de enterramento para pupação. Entomol. Vect. 10, 211- 222.

Gomes, L., Von Zuben, C. J., Sanches, M. R. (2003), Estudo da dispersão larval radial pós-alimentar em Chrysomya megacephala (F.) (Diptera: Calliphoridae). Revsta Bras. Entomol. 47, 229-234.

Gomes, L. and Von Zuben, C. J. (2003), Dispersão larval pós-alimentar em Chrysomya megacephala (F.) (Diptera: Calliphoridae): Profundidade, Distância e Peso de enterramento para pupariação. Bios. Jour 18, 67-76.

Goodbrod, J. R. and Goff, M. L. (1990), Effects of larval population density on rates of development and interactions between two species of Chrysomya (Diptera: Calliphoridae) in laboratory culture. J. Med. Ent., 27,338-343.

Greenberg, B. and Szyska, M. L.. (1984), Immature stages and biology of fifteen species of peruvian Calliphoridae (Diptera). Ann. Ent. Soc. Am., 77, 488517.

Greenberg, B. (1988), Chrysomya megacephala (F.) (Diptera: Calliphoridae) collected in North America and notes on Chrysomya species present in the New World. J. Med. Ent., 25, 199-200.

Greenberg, B. (1990), Behavior of postfeeding larvae of some Calliphoridae and a muscid (Diptera). Ann. Entomol. Soc. America 83, 1210-1214.

Guimarães, J. H., Prado, A. P. and Buralli, G. M. (1979), Dispersal and distribution of thre e newly introduced species of Chrysomya RobineauDesvoidy in Brazil (Diptera, Calliphoridae). Revta. Bras. Ent., 23, 245-255.

Hanski, I. (1977), Biogeography and ecology of carrion flies in the Canary Islands. Ann. Ent. Fenn., 43, 101107.

I. (1987), Carrion fly community dynamics: patchiness, seasonality and coexistence. Ecol. Ent., 12, 257-266.

Kocarek, P. (2001a), Diurnal activity rhythms and niche differentiation in a carrion beetle assemblage (Coleoptera: Silphidae) in Opava, the Czech Republic. Biol. Rhythm Res., 32, 431-438.

Kocarek, P. (2001b), Diurnal patterns of postfeeding larval dispersal in carrion blowflies (Diptera : Calliphoridae). Eur. J. Ent., 98, 117-119.

Legner, E. F. (1977), Temperature, humidity and depht of habitat influencing host destruction and fecundity of muscoid fly parasites. Entomophaga, 22, 199-206. 
Levot, G. W., Brown, K. R. and Shipp, E. (1979), Larval growth of some calliphorid and sarcophagid Diptera. Bull. Ent. Res, 69, 469-475.

Maldonado M. A. and Centeno N. (2003), Quantifying the potencial pathogens transmission of the blowflies (Diptera: Calliphoridae). Mem. Inst. Oswaldo Cruz, 98, 213- 216.

Peschke, K., Krapf, D. and Fuldner, D. (1987), Ecological separation, functional relationships, and limiting resources in a carrion insect community. Zool. Jahr. Abt. Syst. Ökol. Geog. Tiere, 114, 241265.

Prado, A.P. and Guimarães, J.H. (1982), Estado atual de dispersão e distribuição do gênero Chrysomya Robineau-Desvoidy na região Neotropical (Diptera: Calliphoridae). Revta. Bras. Ent., 26, 225-231.

Smith, K. G. V. (1986), A manual of forensic entomology. The Trustees of the British

Turchin, P. (1989), Population consequences of aggregative movement. J. of Anim. Ecol. 58, 75- 100.

Ullyett, G. C. (1950), Competition for food and allied phenomena in sheep-blowfly populations. 1950. Philip. Trans. Royal Society of London B234, 77174.

Von Zuben, C. J., Bassanezi, R. C., Reis, S. F., Godoy, W. A. C. andZuben, F. J. V. (1996), Theoretical approaches to forensic entomology: I. Mathematical model of postfeeding larval dispersal. Jour. Appl. Entomol. 120, 379-382.
Von Zuben, C. J., Bassanezi, R. C. and Von Zuben, F. J. (1998), Theoretical approaches to forensic entomology: II. Mathematical model of larval development J. App. Ent., 122, 275-278.

Wells, J. D. (1991), Chrysomya megacephala (Diptera: Calliphoridae) has reached the continental United States: review of its biology, pest status, and spread around the world. J. Med. Ent., 28, 471-473.

Wells, J. D. and Greenberg, B. (1992a), Rates of predation by Chrysomya rufifacies (Macquart) on Cochliomyia macellaria (Fabr.) (Diptera: Calliphoridae) in the laboratory: Effect of predator and prey development. Pan-Pac. Ent., 68, 12-14.

Wells, J. D. and Greenberg, B. (1992b), Laboratory interaction between introduced Chrysomya rufifacies and native Cochliomyia macellaria (Diptera: Calliphoridae). Env. Ent., 21, 640-645.

Wells, J. D. and Greenberg, B. (1992c), Interaction between Chrysomya rufifacies and Cochliomyia macellaria (Diptera: Calliphoridae): the possible consequences of an invasion. Bull. Ent. Res., 82, 133137.

Zumpt, F. (1965),Myiasis in man and animals in the Old World. Butterworths, London.

Museum, London.

Zar, J. H. (1999), Biostatistical Analysis. Prentice Hall, New Jersey 